The 1970s was a political crossroads for Republican women. Although Schlafly lost a competitive bid for the Federation presidency to a pro-Equal Rights Amendment moderate in 1967, she quickly established an independent organization that gave rise to the Stop-ERA campaign and Eagle Forum. The moderate Ford administration demonstrated its support for equal rights and appointed Smith to chair the RNC. Ford's defeat in the 1976 presidential election, however, shattered opportunities for Republican feminists while conservatives such as Schlafly successfully lined up behind Ronald Reagan. "Republican feminists," Rymph points out, "had to acknowledge that the image they were promoting - of a Republican Party open to feminism - was losing its basis in reality. Increasingly, Phyllis Schlafly was coming to represent, in many people's minds, the Republican Woman" (227). Republican feminists - integrationists - were increasingly marginalized by the now conservative separatists.

Rymph contributes an important perspective to a growing body of scholarship on partisan women. Her sweeping analysis of seven decades of Republican women provides a much needed comparative framework for the study of Democratic women, and it prepares new ground for local and regional studies. How, for example, did Iowa's Republican women respond to the various changes in Federation leadership? How did their clubs affect political outcomes? Theoretical underpinnings in Rymph's analysis can inform such studies. The meaning of citizenship, women's political style and culture, and gendered issues of power, equality, and difference, for example, ground many of Rymph's insights. Indeed, she does justice to the history of Republican women and lays a solid foundation for further studies.

\title{
A Biography of Lillian and George Willoughby, Twentieth Century Quaker
} Peace Activists, by Gregory A. Barnes. Lewiston, NY: Edwin Mellen Press, 2007. xvii, 321 pp. Illustrations, notes, appendixes, bibliography, index. $\$ 119.95$ cloth.

Reviewer Bill Douglas lives and works in Des Moines. His article, "Penn in Technicolor: Cecil Hinshaw's Radical Pacifist-Perfectionist Experiment at William Penn College, 1944-1949," appeared in Quaker History (Fall 2007).

This well-researched, sympathetic dual biography of two lifelong American peace activists helps place the Philadelphia-based Movement for a New Society (MNS) in context, and portrays two extraordinary multidecade careers of opposing war from the 1940s to the present decade. The book starts with an evocative baby boomer family conference on what parents are still capable of, with a twist: Can Lillian, 
who uses a wheelchair, serve her jail sentence for civil disobedience in opposing the U.S. attack on Iraq? (She can.) Readers should bookmark appendix 2, the glossary of acronyms, for Barnes abets the tendency of American pacifists to create organizations at every opportunity. This was magnified by MNS, which finally seems to have imploded from its own incessant self-analysis. But some MNS figures preceded and transcended this cul-de-sac, including the Willoughbys, whose activism - conscientious objection in World War II; American Friends Service Committee work in Des Moines; support for conscientious objectors in Philadelphia; links with pacifist movements in India, Sri Lanka, and Southeast Asia; and constant attention to what Quakers call the workings of the Spirit-resulted in a remarkable pair of lives, though not without tensions.

Barnes makes a few mistakes: Norman Thomas was not, by 1944, a pacifist; Pittsburg, Kansas, does not have an "h." A perceptive foreword by Emma Jones Lapansky-Werner helps put the Willoughbys in the larger context of Quaker practice. A well-done index serves Iowa researchers well-Lillian was born and raised a Quaker in West Branch, and George was adopted in his teens by a teacher in Des Moines and went to the University of Iowa, where he met Lillian, who was working in the library. Barnes comments on the parallels between Lyle Tatum's pacifist career and George Willoughby's; the parallels could be expanded to include American Friends Service Committee staffer Wilmer Tjossem, Quaker lobbyist E. Raymond Wilson, direct action leader Marj Swann, and nonviolent yacht captain Earle Reynolds, who all hailed from Iowa.

Feingold: A New Democratic Party, by Sanford D. Horwitt. New York: Simon \& Schuster, 2007. 287 pp. Illustrations, notes, index. \$26.00 cloth.

Reviewers Glen Jeansonne and David Luhrssen are colleagues in Milwaukee. Jeansonne, professor of American history at the University of WisconsinMilwaukee, is writing a study of the presidency of Herbert Hoover. Luhrssen, author of numerous articles and essays, has lectured at Marquette University and Beloit College.

Russ Feingold, after serving in the Wisconsin state senate, slipped into a U.S. Senate seat in 1992 when two better-known candidates, Congressman Jim Moody and wealthy businessman Joe Checota, attacked each other viciously, ignoring Feingold as inconsequential. The meanspirited tone of Feingold's opponents turned Wisconsin voters in his direction. Feingold started an early, door-to-door campaign as a gritty underdog, husbanding his limited campaign pot for last-minute, self- 